\title{
THE DEVELOPMENT OF TEACHING MATERIAL BASED ON SAVI APPROACH ON “TEMBANG DOLANAN" MATERIAL FOR ELEMENTARY SCHOOL STUDENTS
}

\author{
Panji Kuncoro Hadi \\ Universitas PGRI Madiun, Indonesia \\ panjikuncorohadi@yahoo.co.id
}

\author{
Endang Sri Maruti \\ Universitas PGRI Madiun, Indonesia \\ marutiendang@gmail.com
}

\author{
Hartini \\ Universitas PGRI Madiun, Indonesia \\ hartiniseniputri@gmail.com
}

\begin{abstract}
The purpose of this research is to develop teaching material of SAVI approach on play song "tembang dolanan" material for elementary school students in Madiun Residency. This development research refers to the 4-D method. The research started from February 2017 until November 2017. The research data was validation result. The research instrument used is validation sheet, questionnaire, and students singing (nembang) test. The Data collection techniques were validation and observation. Data were analyzed descriptively qualitative. The results showed that: (1) the process of developing teaching materials SAVI approach on the material tembang dolanan for fourth graders of elementary school in the Madiun Residency consists of three stages. The stage is the stage of definition, stage of design stage, and stage of development; (2) student textbooks SAVI approach on materials " tembang dolanan" for fourth graders of elementary school in Madiun Residency reliability level is very high, that is $89.7 \%$; and (3) based on the calculation, the $t$ count is 7.31 , while the $t$ table is 3.56. Because $\mathrm{t}_{\text {count }}>\mathrm{t}_{\mathrm{table}}$ then $\mathrm{H} 1$ accepted. It is stated that the teaching materials SAVI approach on the material " tembang dolanan" for fourth grade elementary school in Madiun Residency was effectively used.
\end{abstract}

Keywords: development, teaching material, SAVI, tembang dolanan, elementary school, Madiun Residency

\section{INTRODUCTION}

One of teaching materials that can be used as a guide for teachers in teaching is a textbook. According to Sitepu (2012), the textbook is a reference book used in elementary and secondary education units or colleges that contain learning materials in order to improve faith, devotion, noble character and personality, mastery of science and technology, enhanced sensitivity and ability aesthetic, kinesthetic and healthcare enhancement that is compiled based on Indonesia national standard. It means that textbooks can be used as guidance by students and teachers in learning activities because in textbooks there are instructional materials that are able to develop the potential and creativity of students, so it will create changes in mindset and behavior of students.

The SAVI approach is a learning approach that combines physical movement with intellectual activity and the use of all senses. In other words, this approach emphasizes that all students have potential and talent and creativity. Potential in students must be trained and developed. To train and develop student potential, students must experience their own learning activities, undertake or demonstrate the meaning of the learning activity, and use their thinking skills to take action. According to Meier (2005), learning can run effectively as well as attractively if learning can involve all elements of SAVI (Somatic, Auditory, Visual, Intellectual). Somatic is learning by doing motion and action. Auditory is learning by speaking and listening. Visual is learning by observing and describing and Intellectual is learning by solving problems and reflecting. In other words, the SAVI approach has benefit in learning activities when the four elements of SAVI exist in a learning process.
Based on the observations, facts, and results of interviews with teachers, so far the learning of tembang dolanan (play singing) in the subjects of Java language is still very limited. Besides, the materials are not well prepared and lack of using media is also an obstacle. The teaching learning process in the classroom, usually teacher only teach classical "tembang" material without any media. The media as simple as manila or cardboard is not available, the teacher only writes the lyrics or "tembang tembang (lyrics)" on the blackboard, then the teacher gives an example by singing just one song to be taught, then classically telling the child to repeat and lastly hold a test. Based on the problem above, this research seeks to develop teaching materials (textbooks) with SAVI approach to improve the ability of in singing Java's song called "nembang". The SAVI approach is appropriate to the material of the dolanan tembang because in the play song "tembang dolanan", the students are invited to move (Somatik) mimicking the movements that exist in the lyrics of the dolanan song, then redeveloping the heard tembang dolanan (audio) and seen (visual) through VCD, Intelectual) messages contained in the lyrics of the dolanan (play) song. In addition, to help teachers improve the quality of learning atmosphere, such as fun and interesting for students especially in nembang (singing) skills.

\section{METHODS}

The type of research was research and development (R \& D). The study of the development of teaching materials using SAVI approach in tembang dolanan material for fourth grade elementary school used the design of Thiagarajan model known as 4-D model (define, design, develop, and desseminate dissemination) or adapted into a 4-P model (defining, designing, development, and distribution). The data 
was in the form of a series of activity descriptions and activity results from the defining phase, the designing stage, the developing stage and the dissemination stage. While quality data of teaching materials using SAVI approach in tembang dolanan material for fourth grade students in elementary school in the form of quality teaching materials developed based on the product (the quality of content, the quality of presentation, the quality of language, and the quality of layout) and based on the user (learning outcomes and student responses). The data for the development process of teaching materials using SAVI approach in tembang dolanan used validation technique.

This research used a data collection instrument in the form of: (1) data collection instrument for development of teaching materials using SAVI approach in tembang dolanan material (development process data) is a validation material instructional tool instrument SAVI for validator team (material expert, presentation, language and graphic); and (2) the data collection instrument for the quality of teaching materials developed based on the product and its users used the test technique, response questionnaire and validation instrument sheet. Data analysis of teaching materials development process by SAVI approach of tembang dolanan material was done by descriptive technique. Descriptive technique was done from the defining stage to the development stage, while for data derived from the expert validator was analyzed by quantitative descriptive technique with criteria calculation Likert scale.

\section{RESULT AND DISCUSSION}

The purpose of this study is to describe the process of development and quality of teaching materials using SAVI approach on the material tembang dolanan for fourth grades elementary school students in Madiun Residency. The description of each steps and the results that have been obtained in each of the research objectives explained as follow.

1. The Process of Development Teaching Materials (Textbook) using SAVI Approach on tembang dolanan Material for $4^{\text {th }}$ Grade Elementary Schhol Students

In general, the process of development teaching materials using SAVI approach on the material tembang dolanan for fourth grade of elementary school students in the Madiun Residency consists of three stages namely: definition stage, design stage, and of development stage.

a. Definition Stage

This stage had done several steps, namely: the pre and post analysis, students' analysis, concept analysis, task analysis, and analysis of learning objectives. The first step in the preliminary analysis is to identify the the basic problems. This identification was conducted by observing the lessons, interviewing the fourth grade students, discussing with the Javanese teacher. The activities that include in students'analysis was to describe the needs of students in learning Java, especially "tembang dolanan". This analysis was done and focus on characteristics, and experiences of students, both groups and individuals. Students' characteristics include academic ability, age, maturity level, motivation to join the lessons, experience, skills and so on (Depdiknas, 2006). The results of this analysis were as an overview to develop teaching materials using SAVI approach on the material tembang dolanan for fourth graders of elementary school in Madiun Residency.

Task analysis included the understanding and tasks that will be performed by students in accordance with the subject matter and indicators of student learning outcomes (Depdiknas, 2008). This analysis was done by detailing the content of teaching materials in the form of outlines and the preparation of lesson plan. Learning objectives analysis were conducted to formulate indicators of learning outcomes based on concept analysis and task analysis. The indicator was an elaboration of the basic competencies in the curriculum (Ibrahim, 2001). Furthermore, the goal was the background for the preparation of developing teaching materials using SAVI approach on the material tembang dolanan for fourth graders of elementary school in Madiun Residency.

\section{b. Designing Stage}

The designing stage was aimed to obtain the initial format or draft of developed teaching materials. This stage as a reference to compile teaching materials using SAVI approach on materials tembang dolanan for fourth graders of elementary school in Madiun Residency. Teaching materials are written, pay attention to the accuracy of the contents, the accuracy of the presentation, the accuracy of language and the accuracy of graphic (Trianto, 2007). The steps of the activity were writing, adopting, making teaching materials. Teaching materials that have been written and then compiled and re-read as an editing activity. This activity was done to check and corect the language errors and spelling. Teaching materials produced was a draft I of teaching materials using SAVI approach on the material tembang dolanan for fourth graders of elementary school in Madiun Residency.

In general, the designing stage includes two steps, namely the selection of material form and material initial design. The form of teaching material using SAVI's approach was prepared then got suggestions from experts and colleagues. Designing stage was the main activity in designing teaching materials using SAVI approach on the material tembang dolanan for fourth graders SD in Madiun Residency. In designing teaching materials using SAVI approach, researchers got sugestions and advices from experts, Javanese language teachers and peers, so that the desired design is obtained.

\section{c. Developing Stage}

This stage was aimed to produce teaching materials using SAVI approach on the material tembang dolanan for fourth graders of elementary school in the Madiun Residency. The draft I that has been compiled was validated by the expert validator, they are: the presentation expert, the material expert, the linguist, and the layouting expert. Based on 
suggestions from validator of draft I, the teaching material was revised. The revision of teaching material was called draft II. Then, Draft II was tested limited. Before the implementation of a limited trial was tested, subjects were tested to determine the initial ability of the subject. After a limited trial was conducted, the subjects were interviewed and tested to determine students' understanding of the learning. After a limited trial done, the larning materials developed were revised suitable with the results of the limited trial. The result is called draft III. Draft III was tested extensively. The steps taken by researchers in draft III were same as the steps in draft II. Before implementation of extensive testing, the subject was tested to determine the initial ability of the subject. After extensive trials were conducted, the subjects were interviewed and tested to determine students' understanding of the learning. After extensive trials conducted, the developed materials were revised in accordance with the results of extensive trials. The results of interviews and test results are used as consideration to improve the draft teaching materials. Thus, draft IV is the result of teaching materials using SAVI approach.

\section{d. Disseminating Stage}

The dissemination stage was the final stage of the research. It was done to disseminate teaching materials that have been made completely. The dissemination of SAVI's teaching materials was conducted during meetings of the Teachers Working Group (KKG) and / or MGMP (Javanese Subject Teachers) in the school environment.

2. The Quality of Teaching Materials using SAVI approach on tembang dolanan Material for $4^{\text {th }}$ Grade of Elementary School Students Based on the Product

The quality of teaching materials using SAVI's approach in tembang dolanan material for fourth grade elementary school students in Madiun Residency can be determined from the validation result. Overall, the teaching materials were validated in four aspects; based on material, language, presentation, and layout.

a. Students Textbooks Validation Based on Content/Material Expert

The material elements in the learning materials of the students developed were substantial and important. the content/material aspects of students' textbook consist of three components, namely the content/material conformity, the accuracy of the material, and learning support materials. Overall, the content feasibility component obtained a score of 33 from the validator. Based on these scores, the reliability level of the competency component of teaching content was $82.5 \%$. It shows that the eligibility of teaching material content of students has been reliable. Based on these results, the general assessment conclusion is that if the student textbook developed in this study is good and can be used with little revision. b. Student Textbook Validation Based on Language Expert

The language elements was also important because the content / material is delivered through the language. Good or not the content quality was determined by the language used. Language assessment aspect of student textbook consists of three components, namely conformity with the level of development of students' language, communicative, coherence, and unity. Overall, the language feasibility component got score of 30 from the validator. Based on these scores, the reliability level of the language feasibility component of student learning material is $85.7 \%$. It shows that the language in the student textbook is reliable. Based on these results, the general assessment conclusion is that if the student textbook developed in this study is good and can be used with little revision.

\section{c. Student Textbooks Validation by Presentation Format Expert \\ The textbook also needs to be validated based} on the presentation format. The presentation assesment aspect of students textbook consists of three components, namely: presentation techniques, presentation of learning, and completeness of presentation. Overall, the presentation feasibility component obtained a score of 45 from the validator. Based on these scores, the reliability level of the feasibility component of student teaching material presentation is $90 \%$. It shows that the presentation of textbook students is reliable. Based on these results, the general assessment conclusion is that if the student textbook developed in this study was good and can be used with little revision.

\section{d. Student Textbooks Validation Based on Layout Expert}

The layouting element in the learning material was essential and important (Trianto, 2007). Layouting assessments of textbooks consists of three components, namely the size of the book, the design of skin cover, and the design of the contents. Overall, the feasibility component of the graduate obtained a score of 46 from the validator. Based on these scores, the reliability level of the feasibility component of students' teaching material graduation is $83.6 \%$. It shows that students' textbook graduation is reliable. Based on these results, the general assessment conclusion that this students' textbook was good and can be used with little revision.

Based on the four validation results above, the average level of student textbook reliability is $89.7 \%$. The results indicated that the reliability level of student textbook using SAVI approach on the material tembang dolanan for fourth graders of elementary school in the Madiun Residency was very high.

3. The Quality of Teaching Materials (Textbooks) using SAVI Approach on Tembang Dolanan Material for 4th Grade Students Based on Users/Learners/Students

Learning materials that have been developed and validated by experts and declared eligible to be 
used or applied as learning materials in teaching and learning activities, then implemented or applied in learning activities on fourth graders of elementary school in Madiun residency. This is intended to know the implementation of learning materials using SAVI approach in the class. Research subjects Test I was a fourth grader, about 29 students. In the implementation of test I, three lessons were conducted by the researcher, outside of the pre-test of one meeting and one meeting for post-test.

a. Students' Response

Student responses were obtained from a questionnaire of students responses given to each student after following the implementation of Javanese language learning material with SAVI's approach on the material of the tembang dolanan for the fourth grade of elementary school students in Madiun Residency. An average of 26 students or nearly $90 \%$ of students were happy in using the textbook, and only 3 students or $10 \%$ are admitted unhappy. From 29 students who took the test, only two students or $10 \%$ of students thought that the language in Javanese language learning material with SAVI approach on the material tembang dolanan was not good. In terms of presentation format consisting of writing, drawing illustrations, and drawing layout, most of the students' responses state that if the Java Language learning material with SAVI's approach on temabang dolanan material for fourth grade students in Madiun residency was interesting. $96.55 \%$ of students expressed interestend and the rest, only one student or less than $3.45 \%$ just claimed not interested in this textbooks.

Around 28 students or $96.55 \%$ of students expressed interested and admitted like in this textbooks. Only one student or about $3.45 \%$ of students who expressed not interested in learning activities in Java language using SAVI approach on tembang dolanan materials for fourth grade elementary school students. Based on the data obtained, about 28 students or $96.55 \%$ of students said assisted and trained well using this textbook. Based on the five responses of students related to the learning of Javanese language using this textbook above, it can be concluded that it was fun, interesting, interested in learning, easy to understand, and very useful to train students' selfconfidence. Thus, the Javanese language learning material with SAVI's approach on the material of the temabng dolanan for the fourth grade of elementary school students was approved by the students to be applied.

\section{b. Students learning outcomes}

The tes result is used to know the success or not of using learning material (textbooks) with SAVI approach on tembang dolanan material. The test result of the learning was done twice that is the initial test to know the student's early ability before using the learning material (pre-test) and the final test done after using the learning material (post-test). The completeness of student learning outcomes was based on the minimum established standard of completeness. The value of the specified standard of completeness individually is $\geq 70$ and the established standard of classical completeness is $\geq 80 \%$.

Based on the data obtained, pretest results in the class of broad trials there are thirteen students who completed individually with a value of 70 . For posttest results of 29 existing students, 25 students expressed individually and 4 students declared not yet completed individually based on the value achieved. For classical completeness the average was 80 , based on the minimum defined standard score, the posttest result is declared complete. Judging from the results of learning by using learning materials (Java language textbooks) with SAVI approach on the material tembang dolanan are very positive. Students are more enthusiastic to learn because they learn more fun, interesting, add interest in learning, easy to understand, and very useful to train students in overcoming belief in nembang dolanan.

\section{CONCLUSION}

In general, during the process of development teaching materials using SAVI approach on the material tembang dolanan for fourth graders elementary school in Madiun Residency consists of three stages. The stages were stage of definition, stage of designing stage, and stage of development. The quality of Javanese instructional material with SAVI approach on the material of dolanan tembang for fourth grade students of elementary school in Madiun Residency developed can be determined from the validation results. Overall, the textbook was validated on four aspects, based on content, language, presentation, and layout.

In the students' textbook, the content feasibility component obtained a score of 33 with a reliability level of $82.5 \%$. The language feasibility component obtained score of 30 with a reliability level of $85.7 \%$. The presentation feasibility component, the scores 45 with a reliability level of $90 \%$. The feasibility component of the graduation scores was 46 with a reliability level of $83.6 \%$. Based on the four main components above, then the average level of student textbook reliability is $89.7 \%$. The results indicated that the reliability level of student textbook using SAVI approach on the tembang dolanan material for fourth graders of elementary school in the Madiun Residency was very high.

The student's response of SAVI's teaching materials on the tembang dolanan materials was fun, interesting, adds interest in learning, easy to understand, and very useful for training students in coping with student's fame in nembang dolanan. Thus, the learning material of Java Language with SAVI approach on tembang dolanan material for the fourth grade of elementary schoolstudents was approved by students to be applied. Based on the calculation, the result $t_{\text {count }}$ of 7.31 , while $t_{\text {table }}$ of 3.56 . Because $t_{\text {count }}>$ $\mathrm{t}_{\text {table }}$ then $\mathrm{H} 1$ accepted. It is stated that the teaching materials SAVI approach on the material tembang dolanan for fourth graders of elementary school in Madiun Residency was effective. 


\section{REFERENCES}

[1] Depdiknas. 2006. Pedoman Memilih dan Menyusun Bahan Ajar. Jakarta: Direktorat Sekolah Menengah Pertama, Derektorat Jenderal Pendidikan Dasar dan Menengah, Depdiknas.

[2] Depdiknas. 2008. Panduan Pengembangan Bahan Ajar. Jakarta: Depdiknas.

[3] Ibrahim, M. 2001. Model Pembelajaran Perangkat Menurut Jerolg E. Kemp \& Thiagarajan. Surabaya: Faculty of Matematics and Science University Assosiates.

[4] Meier, D. 2002. The Accelerated Learning Handbook. Bandung: Mizan Media Utama.

[5] Sitepu. 2012. Penulisan Buku Teks Pelajaran. Bandung: PT Remaja Rosdakarya.

[6] Trianto. 2007. Model Pembelajaran Terpadu dalam Teori dan Praktik. Jakarta: Prestasi Pustaka.

[7] Trianto. 2011. Model Pembelajaran Terpadu: Konsep, Strategi, dan Implementasinya dalam Kurikulum Tingkat Satuan Pendidikan. Jakarta: Bumi Aksara. 